\title{
Basic Aspects of Children's Speech Training for School by Using Activity and Personality Approach
}

\section{Aspectos básicos del aprendizaje del habla de los niños para la escuela mediante el uso de un enfoque de actividad y personalidad}

\author{
Olena Kovshar* \\ Kryvyi Rih State Pedagogical University, Kryvyi Rih, Ukraine. \\ ORCID: https://orcid.org/0000-0003-3407-8570 \\ Inna Inshakova \\ Kryvyi Rih State Pedagogical University, Kryvyi Rih, Ukraine. \\ ORCID: https://orcid.org/0000-0001-7584-6308 \\ Artur Inshakov \\ Kryvyi Rih State Pedagogical University, Kryvyi Rih, Ukraine. \\ ORCID: https://orcid.org/0000-0002-6541-6918
}

*Correspondence

Email: olena.kovshar@mail.ru
Cite as:

Kovshar, O., Inshakova, I., \& Inshakov, A. (2020). Basic Aspects of Children's Speech Training for School by Using Activity and Personality Approach. Propósitos y Representaciones, 8 (SPE2), e688. Doi: http://dx.doi.org/10.20511/pyr2020.v8nSPE2.688 


\section{Summary}

The research is devoted to the problem of speech training of preschool children before they begin studying at school. The terms "speech training for school", "general speech training", "special speech training" have been clarified. The essence and structure of the phenomenon of "communication and speech competence" are revealed, the criteria, indicators and levels of communication and speech competence are described. The experimental method of speech training for school by using activity and personality approach is researched. The speech readiness for learning is highlighted as a main condition for entry into the learning environment and a further successful learning start. The analysis of researches of modern scientists devoted to the phenomenon of "children's speech training for school" (A. Bohush, M. Vashulenko, L. Kalmykova, N. Shylina) is conducted. It is revealed that the result of speech training is the formation of speech and communication competence of preschool age children. The criteria of speech and communication competence were phonetic, lexical, grammatical, diamonological competence with relevant indicators. Formation of speech and communication competence in the process of speech training by means of activity and personality approach involves the introduction of a specially developed program of speech training of older preschoolers before they get into studying at school: communication and speech situations, play-based speech exercises, variative dialogues. The results of the research confirmed the effectiveness of the proposed program for the formation of communication and speech competence in the process of speech training of older preschoolers before their studying at school.

Keywords: Speech Training for School; General Speech Training; Special Speech Training; Communication and Speech Competence; Implementation of an Activity and Personality; Approach in Speech Training for School.

\section{Resumen}

La investigación está dedicada al problema del entrenamiento del habla de los niños en edad preescolar antes de que comiencen a estudiar en la escuela. Se han aclarado los términos "entrenamiento del habla para la escuela", "entrenamiento general del habla", "entrenamiento especial del habla". Se revela la esencia y estructura del fenómeno de la "competencia comunicativa y del habla", se describen los criterios, indicadores y niveles de competencia comunicativa y oral. Se investiga el método experimental de entrenamiento del habla para la escuela mediante el uso de un enfoque de actividad y personalidad. La preparación del habla para el aprendizaje se destaca como una condición principal para entrar en el entorno de aprendizaje y un nuevo comienzo exitoso del aprendizaje. Se lleva a cabo el análisis de las investigaciones de los científicos modernos dedicados al fenómeno del "entrenamiento del habla de los niños para la escuela" (A. Bohush, M. Vashulenko, L. Kalmykova, N. Shylina). Se revela que el resultado del entrenamiento del habla es la formación de la competencia del habla y la comunicación de los niños en edad preescolar. Los criterios de competencia en habla y comunicación fueron competencia fonética, léxica, gramatical, diamonológica con indicadores relevantes. La formación de la competencia del habla y la comunicación en el proceso de entrenamiento del habla mediante el enfoque de actividad y personalidad implica la introducción de un programa especialmente desarrollado de entrenamiento del habla para niños en edad preescolar mayores antes de que comiencen a estudiar en la escuela: situaciones de comunicación y habla, habla basada en el juego ejercicios, diálogos variativos. Los resultados de la investigación confirmaron la efectividad del programa propuesto para la formación de la comunicación y la competencia del habla en el proceso de entrenamiento del habla de los niños en edad preescolar mayores antes de estudiar en la escuela.

Keywords: Entrenamiento del habla para la escuela; Entrenamiento del habla general; Entrenamiento especial del habla; Competencia en comunicación y habla; Implementación de una Actividad y Personalidad; Enfoque en el entrenamiento del habla para la escuela. 


\section{Introduction}

The foundation of the future personality is laid at preschool age, and the future of the state is determined by the level of education of its youngest citizens - children of preschool age.

The problem of preparing children for school was studied by many scientists: Ye. Arkin, L. Venger, L. Vyhotskyi, P. Honcharuk, D. Elkonin, O. Zaporozhets, V. Kotyrlo, H. Kravtsov, O. Kravtsova, O. Leontiev, O. Liubchyk, T. Markova, N. Menchynska and others. (psychological readiness of children for school and readiness for learning); T. Babaieva, A. Bohush, Z. Borysova, F. Bliekher, O. Vodovozova, H. Lavretieva, F. Levin-Shchyrina, V. Lohinova, Z. Mykhailova, M. Morozova, H. Petrochenko, O. Proskura, Ye. Tykhieieva, O. Usova, Ye. Floryna, O. Funtikova, V. Yadeshko and others (mental development of children and preparation for school); A. Arushanova, A. Bohush, N. Havrysh, L. Kalmykova, K. Krutii, N. Savinova, O. Tryfonova, N. Shylina and others. (formation of speech skills in the process of educational and speech activity of children and speech training before the studying at school).

Purpose of the article: to investigate the effectiveness of the program of children's speech training for school by means of activity and personality approach

The following tasks are set to achieve the goal of the research:

1. To clarify the term of "speech training for school"; "general speech training", "special speech training". To reveal the essence and structure of the phenomenon "communication and speech competence", criteria, indicators and levels of the researched phenomenon.

2. To investigate the effectiveness of the experimental program of speech training of older preschoolers for school by means of activity and personality approach.

The experiment involved 258 children of preschool age in Kryvyi Rih city, Kryvyi Rih district and Dnipro city.

\section{Research methods}

In order to solve these problems, we used a set of research methods: theoretical: methods of comparative and systematic analysis for comparing different views on the researched problem, definition of the conceptual and categorical apparatus of the research, substantiation of the methodological foundations of children's speech training for school; empirical methods: to study the state of children's speech training for school; diagnostic methods and pedagogical experiment were applied; observational methods (observations) to identify the levels of children's speech training for school.

\section{Results}

The readiness of the child for school education as a complex, multilevel concept has its traditions in the psychological and pedagogical scientific literature (K. Bardin, B. Blum, A. Bohush, L. Bozhovych, H. Vashchenko, L. Venger, O. Venger, L. Vyhotskyi, Yu. Hilbukh, N. Hutkina, D. Elkonin, L. Zhurova, O. Zaporozhets, H. Kostiuk, O. Kravtsova, H. Liublinska, O. Leontiev, S. Maksymenko, V. Mukhina, N. Nyzhehorodtseva, H. Petrochenko, H. Tsukerman, V. Shchadrykov and others). Scientists insist on the need to form a certain level of readiness of children for studying at school, to form different types of competencies in them in accordance with the Basic component of preschool education (BKDO) (the State Standard for Preschool Education). 
We consider school readiness as a complex multicomponent formation where the following components are optimally combined: physical, psychological and personal, covering all major areas of the child's development. The totality of their actual manifestation is the basic competence of the personality of the older preschooler before entering the school.

Among the main characteristics of the personality of the preschooler are the personal experience that the child has at the time of entering the school and the ability to interact with other people. The speech communication itself guarantees the child complete social and psychological protection and promotes successful learning activities in the future.

Consequently, the speech readiness for studying at school is singled out as the basic condition for a child to enter a new learning environment.

Training of children's speech for school has been the subject of research of many scientist: both in Ukraine (A. Bohush, M. Vashulenko, A. Ivanenko, L. Kalmykova, N. Shylina) and abroad (L. Aidarova, A. Arushanova, H. Bieliakova, D. Elkonin, L. Zhurova, A. Markova, L. Penievska, F. Sokhin, S. Strunina, O. Ushakova).

The central qualitative growth of older preschoolers is "the emergence of regulatory, planning functions of speech" according to L. Vyhotskyi (Vyhotskyi, 2000). The child acquires connected, contextual speech, which contributes to the formation of generalizing function of speech of the first-graders and provides going beyond spontaneous situations.

A. Bohush notes that the training of children's speech for school involves mastering their practical speech skills, improving communicative forms and functions of speech, forming its awareness; mastering speech as a tool of communication, perception, regulation of behavior. Such training enables the future scholar to develop the right tactics of communication in a timely manner, avoid difficulties in dealing with adults and children of the same age, unwanted conflicts (Bohush, 2003).

The subject of N. Shylina's research was the formation of the speech readiness of older preschoolers for studying at school. The obtained results showed that effective pedagogical conditions for the formation of speech readiness of children are: communicative and speech orientation of learning; language belonging to different directions of activity (educational and cognitive, educational and speaking, artistic and speaking, theatrical and playing, communicative); a comprehensive approach to the development of speech and speech learning; adequate motivation for communication and speech activities; involvement of parents in working together to enhance communication and speech development of children (for experimental groups of children who did not attend preschool) (Shylina, 2003).

According to K. Krutii, "children's speech training for school" is the complex usage of language and non-linguistic means by the child to use language units for thinking, communicating, and realizing one's self in the process of life (Krutii, 2009).

L. Kalmykova views "speech training" as a system containing two components: general speech training and special training. General speech training provides the development of oral, communication skills, the development of speech perception and understanding, the acquisition of speech experience and sense (when entering school, the child must speak his or her native language, learn its literary norms, culture of oral speech and communication); special training involves the teaching of language propaedeutics - the initial awareness of the sign system of language, the formation of the basics of linguistic and speech skills in the field of reading and writing, analysis of speech phenomena, the development of conscious speech. Special training is divided into: linguistic (cognitive and reflectory) and speech (communicative and reflectory) training, which provides the propaedeutics of language learning - the initial reflection on linguistic material. Special language training is only available for the fifth year of the child's life; it begins 
with the giving of information about primary language knowledge to children, and ends with elementary reading and writing skills, analysis of linguistic units, and is controlled by consciousness (Kalmykova, 2000).

Therefore, the general speech training of children for school implies the adaptation of children in regards to mastering the rules of speech, the speech actions required to master speech skills.

Special speech training of children for school is carried out at special classes on speech development, sound analysis of words and teaching children the elements of literacy in accordance with program requirements.

The criteria for determining the level of development of a child of preschool age (according to the requirements of BKDO) are based on personality and activity approaches. A harmoniously developed personality is the goal of education, the end result, and the activity of a preschooler appears as a form of development making, realization of the personality's potential.

L. Vyhotskyi believed that speech, communication and the joint activity of child with other people were of particular importance in the child's mental development (Vyhotskyi, 2000). Such activity acts as an integrative basis of psychic properties and functions.

The activity and personality approach was chosen in the light of the scientific doctrine of activity, leading activity and development of the child's personality in the process of speech activity.

The foundations of the activity and personality approach were laid in psychology by the works of B. Ananiev, L. Vyhotskyi, O. Leontiev, S. Rubinshtein, who considered the personality as a subject of activity, which itself, being formed in activity and in communication with other people, defines nature of this activity and communication. Personality occupies a central position in it; the main content of learning is the development of personality.

The activity and personality approach shapes the activity of the child, his or her readiness for educational activity; it envisages the unity of external and internal motives from the child's point of view. The external motive is the motive of achievement, and the internal one is the cognitive motive, acceptance of the educational task and satisfaction from its solving in cooperation with others, with those, who learn (Ohneviuk, 2006) .

The use of activity and personality approach provides the formation of the foundations of educational activities for older children, full knowledge, mental development and selfdevelopment, because it goes through all its components.

Thus, the activity and personality approach in the context of speech training of preschool children involves: reorientation of learning from traditional learning and memorization of readymade forms of knowledge to the activity process of their obtaining and functioning; acquisition of competencies by the child in the process of preschool education, acquisition of life experience, values, attitudes that are fully realized in the process of a specific educational situation; formation of the main activities - communication, cognitive and educational activities, as the basis for further development and education of the child's personality.

Therefore, we define speech training for school as an active speech activity of a child of older preschool age, her or his ability to actively interact and communicate with others. 
The result of speech training is the formation of speech and communication competence of children of preschool age.

Speech and communication competence involves the complex use of linguistic and nonlinguistic means for communication, intercommunication in specific social and everyday situations, initiation of communication; culture of speech communication.

The criteria for speech and communication competence of the child were the following components with appropriate indicators: phonetic competence (correct pronunciation of sounds, development of phonemic hearing, expressiveness of speech); lexical competence (vocabulary wealth, understanding of the semantics of words); grammatical competence (morphological correctness of speech, syntactic structure of speech, presence of assessment and control actions); diamonological competence (ability to engage in dialogue with a partner, coherent reproductive expressions, coherent creative expressions).

Experimental tasks were developed for each of the criteria we identified to determine the levels of speech and communication competence in the process of training of children's speech for school. The general levels of speech and communication competence in the process of children's speech training for school were determined by the average arithmetic indicator of each type of competence: high, sufficient, intermediate and low.

Formation of speech and communication competence in the process of speech training by means of activity and personality approach involves the implementation of a specially designed program. Implementation of the program of speech training of children of preschool age before their studying at school consisted of the following stages: information and speech, activity and communication, assessment and correction.

Thus, the purpose of the first - information and speech - stage was to enrich children's knowledge with formulas of speech etiquette; dialogical forms of communication. Substantial aspect of the work: lessons on the development of speech, speech situations of communication (dialogue), artistic and speech activity. The topics of communication and speech situations, speech games and exercises were highlighted and various dialogues were developed. For example, "Meeting in the street", "Telephone conversation", "In transport".

In order to familiarize children with the vocabulary of moral and ethical direction, the speech games "Walking Pumpkin", "Ringing!", speech situations "In transport", "Hairdressing salon", "Theater" as games were developed. These games and situations were an integral part of the literature and speech development classes.

The purpose of the second - activity and communication - stage was to immerse children in active speech activity. The substantial aspect of the work included communication classes, language and literature development classes (lexical competence); differentiated speech and communication situations (diamonological competence); replacement of speech etiquette formulas with synonymous play and artistic and speech activity (grammatical competence). The educational task of the implementation of the specified content aspect was the inclusion of language in various activities, the implementation of activity and personality approach to the development of speech and speech learning.

In order to activate speech and communication competence, to stimulate initiative in communication in the second stage, besides the development of speech and literature classes, the children were involved in story and role games and theatrical games (for example, theatrical games "Journey to the fairytale land, "Tangled fairytales" "Colored fairytales", "In the world of fantasy"). For the enrichment of children's knowledge by means of non-linguistic expression, exercises for recognizing different emotional states were offered. For this purpose a set of illustrated cards "Going through pages of favorite fairytales" was used. 
The stimulation of assessment and control actions in communication and speech activity took place in the third - assessment and correction - stage. Substantial aspect of work: speech situations requiring independent search and use of language forms (improvised social and roleplaying games, independent compilation of text), speech situations of communication, speech games, exercises, emotional and speech etudes, games by the content of fictions, conditioned speech actions in various situations, exercises for finding grammatical errors, assessment and control activities of children (self-assessment and mutual assessment, comparison of grades).

In order to form assessment and control actions in speech activity, children were offered exercises for making dialogues and assessing them. Moreover, not only the content of the dialogue was assessed, but also its originality, expressiveness of speech, presence of appropriate polite words.

According to the results of the experimental research, the final assessments on the formation of communication and speech competence for older children of preschool age in the process of speech training before studying at school were made. Comparative data of the levels of communication and speech competence in the process of children's speech training for school are presented in Table 1.

Table 1.

Comparative analysis of levels of formation of communication and speech competence in the process of children's speech training for school at the ascertaining and final stages (\%)

\begin{tabular}{llllll}
\hline $\begin{array}{l}\text { Experiment } \\
\text { stages }\end{array}$ & Group & High level & $\begin{array}{l}\text { Sufficient } \\
\text { level }\end{array}$ & $\begin{array}{l}\text { Intermediate } \\
\text { level }\end{array}$ & Low level \\
\hline Ascertaining & Exp. & 12 & 34 & 36 & 18 \\
& Contr. & 12 & 36 & 28 & 24 \\
Control & Exp. & 26 & 48 & 24 & 2 \\
& Contr. & 16 & 42 & 30 & 12 \\
\hline
\end{tabular}

As the table shows, the children of the experimental groups have made positive changes. Thus, $26 \%$ of children reached a high level of speech training (12\% at the ascertaining stage). As for the children of the control groups, $16 \%$ of the older preschoolers reached a high level (12\% at the ascertaining stage). Children actively engage in, support and end communication; express themselves logically, coherently, independently, at a normal pace; speak clearly; use a variety of linguistic means, speech standards, types of speech expressions; quickly find the right words in different communication situations; dialogues of children are meaningful, their subject matter is diverse.

$48 \%$ of the children of the experimental groups reached sufficient level (34\% before the start of studying). In regards to the children of the control groups: $42 \%$ of the children were now at a sufficient level ( $36 \%$ respectively before the studying). Older preschoolers communicate freely with their peers, use various language means, speech standards, types of speech expressions; the right words are chosen by them in different communication situations. Children are well aware of and adhere to the rules of dialogue. At the same time, their speech is not always expressive. Children do not know how to use well-established language expressions, folk proverbs, sayings. 
The intermediate level was confirmed by $24 \%$ of children (36\% at the ascertaining stage) of the experimental group. The intermediate level of speech readiness of the control group was confirmed by $30 \%$ of children ( $28 \%$ at the ascertaining stage). Children can support and complete the conversation started by the dialogue partners; express themselves in language independently. They react slowly enough to the course of the conversation; use the necessary words in different situations of communication. At the same time, preschoolers do not always adhere to the rules of dialogue; they deviate from its topic. Children's speech is not clear.

The number of children with low levels of speech training in the experimental group decreased from $18 \%$ to $2 \% .12 \%$ of children in the control group were at low level (at the ascertaining stage it was $24 \%$, respectively). Children of this level often deviate from the rules of dialogue. They almost do not use well-established language expressions, folk proverbs, sayings; they are unable to express themselves logically and in a coherent way; they are not able to react quickly to the course of the conversation, to choose the necessary words during the dialogue; they do not use various language means, speech standards and types of speech expressions. Subject and dialogical expressions of these children are quite identical. They do not follow the rules of dialogue while talking to their peers.

Therefore, the results of the research confirmed the effectiveness of the proposed speech training program for older preschoolers before their studying at school.

\section{Conclusion}

Speech training of older preschoolers before their studying at school is the main condition for further successful learning at a new stage.

Speech training for school is defined as an active speech activity of a child of preschool age, his or her ability to actively interact, communicate with others.

Speech training of children for school is distinguished as general speech training (adaptation of children for mastering the rules of speech, speech actions required for mastering speech skills) and special speech training (special classes in speech development, sound analysis of words and teaching children of literacy elements according to program requirements).

The implementation of effective speech training for school is made using activity and personality approach, which provides the acquisition of speech and communication competence by the child in the course of educational speech activity; formation of the basics of communication, communicative interaction, the basics of further speech development for elementary school education.

Therefore, the result of speech training is the formation of speech and communication competence of preschoolers.

Speech and communication competence involves the complex use of linguistic and nonlinguistic means for communication by an older preschool child; implementation of communication skills in specific social situations and adherence to the culture of speech communication.

The criteria of speech and communication competence of the child were the following components: phonetic, lexical, grammatical and diamonological competences with relevant indicators.

The introduction of a specially developed program of speech training for school ensured the formation of speech and communication competence. The analysis of the results of the 
research confirmed the effectiveness of the proposed program of speech training of older preschoolers before their studying at school.

We see further development of the speech training issue in the creation of a transparent speech development program for older preschoolers and first-grade pupils with the principle of coherence and continuity.

\section{References}

Bohush, A.M., Shylina, N.Ye. (2003). Speech readiness of older preschool children before studying at school. Odesa: PNTS of the Academy of Pedagogical Sciences of Ukraine.

Kalmykova, L. (2000). Theoretical basics and ways to improve speech training of children for school. Elementary School, 12, 8.

Krutii, K.L. (2009). Educational space of pre-school educational institution. Kyiv: Education.

Ohneviuk, V. (2006). Special mission of preschool education. Preschool education, 4, 5.

Shylina, N.Ye. (2003). Formation of speech readiness of children of the older preschool age before studying at school: pedagogical sciences candidate thesis. Odesa: South Ukrainian K. D. Ushynsky National Pedagogical University State Institution.

Vyhotskyi, L.S. (2000). The genesis of higher mental functions. Moscow: Eksmo. 